\title{
In vitro propagation studies of Albizia amara (Roxb.) Boiv.
}

\author{
G. Indravathi and T. Pullaiah* \\ Department of Biotechnology, Sri Krishnadevaraya University, Anantapur-515 005, India.
}

Accepted 13 December, 2012

\begin{abstract}
Albizia amara, belonging to the family Fabaceae is a valuable economic, medicinal and multipurpose drought tolerant tree commonly found in dry forests of India. Keeping view of its economic importance, a protocol was developed for rapid clonal multiplication of A.amara by means of plant tissue culture. In the present study, development of complete plantlets via induction of multiple shoots from seedling derived cotyledonary node explant and their successful rooting and acclimatization is reported. Cotyledonary node explants were excised from 12-15 day old aseptic seedlings to initiate culture for multiple shoot induction on MS medium. Among the different plant growth regulators tested either in single or in combination, BAP $1 \mathrm{mg} / \mathrm{l}$, BAP $1 \mathrm{mg} / \mathrm{l}+\mathrm{Kn} 2 \mathrm{mg} / \mathrm{l}$, BAP $1 \mathrm{mg} / \mathrm{l}$ + NAA $1 \mathrm{mg} / \mathrm{l}$ were effective in inducing multiple shoots from cotyledonary node explants. Shoot elongation was prominent at $\mathrm{Kn} 0.25$ $\mathrm{mg} / \mathrm{l}$ concentration. In vitro rooting experiments were successful on half strength MS medium fortified with NAA $1 \mathrm{mg} / \mathrm{l}$.
\end{abstract}

Key words: Albizia amara, tree, micropropagation, axillary bud multiplication.

\section{INTRODUCTION}

Albizia amara (Roxb.) Boiv., belonging to the family Fabaceae, is a valuable economic, medicinal and multipurpose drought tolerant tree commonly found in dry forests of India. The wood of Albizia amara is purplish brown with lighter bands, very hard and strong, used for cabinets in building and agriculture purpose. The bark of the tree yields gum, which is used for ulcers (Kashyapa and Ramesh, 1992) and molluscidal activity (Ayoub and Yankov, 1986). Besides these, the leaves contain a flavanol glycoside namely 4'O-menthylrutin and they are extensively used as herbal cosmetic for hair maintenance. Leaves are also useful in ophthalmia. Budmunchiamines, spermine macrocyclic alkaloid (Mar et al., 1991) extracted from the seeds of $A$. amara were found to interact with DNA by inhibiting the catalytic activity of DNA polymerase, RNA Polymerase, and HIV reverse transcriptase. Albizia is also one among the 10

\footnotetext{
*Corresponding author. E-mail: pullaiah.thammineni@gmail.com. Tel: +91-08554-255561. Fax: +91-08554-255244.
}

major species, which is widely used in plantation forestry programme in India. Kumar et al. (1998) described regeneration of plants from leaflet explants in $A$. procera. Sinha et al. (2000) described in vitro differentiation and plant regeneration in $A$. chinensis. Ramamurthy and Savithramma (2003) described shoot bud regeneration from leaf explants. Micropropagation via axillary bud proliferation was not described in $A$. amara, hence this study was undertaken. This paper describes a reproducible and efficient protocol to regenerate true to type plantlets directly from seedling explants.

\section{MATERIALS AND METHODS}

Healthy seeds of $A$. amara after mechanical separation were washed in an agitated detergent solution $(0.1 \%$ laboline Merck, India) for 5 min followed by thorough washing under a jet flow of tap water for half an hour. Seeds were then scarified with conc. $\mathrm{H}_{2} \mathrm{SO}_{4}$ $(98 \%)$ for $3 \mathrm{~min}$. After scarification, seeds were subjected to repeated washing for 3 to 4 times with sterilized double distilled water (DDW), the seeds were soaked in sterile DDW and incubated at $25 \pm 2{ }^{\circ} \mathrm{C}$ for $24 \mathrm{~h}$. Surface sterilized seeds were inoculated singly on different nutrient media. Various types of surface sterilants like mercuric chloride $\left(\mathrm{HgCl}_{2}\right)$, Sodium hypochlorite $(\mathrm{NaOCl})$ and 


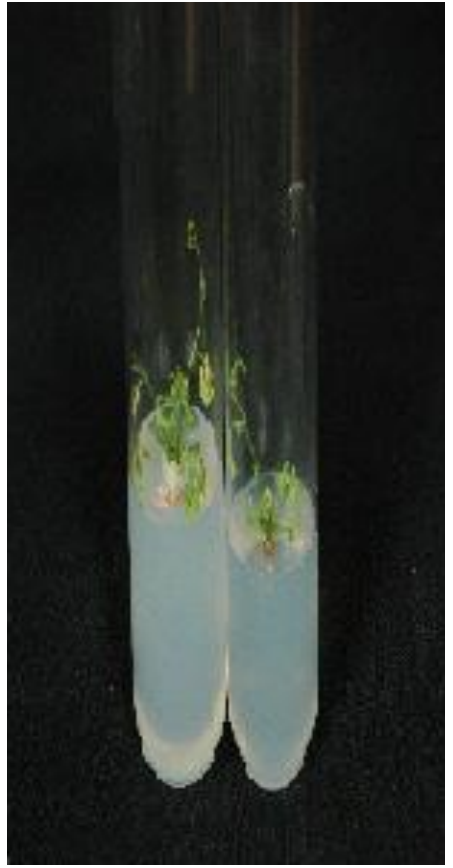

Figure 1. Morphogenetic response of cotyledonary node of A. amara on MS medium.

Hydrogen peroxide $\left(\mathrm{H}_{2} \mathrm{O}_{2}\right)$ were used for sterilizing the seeds in order to raise healthy seedlings. Various experiments were performed to standardize a low cost media for high percent of germination. Tap water + agar, Tap water + agar $+2 \%$ sucrose, MS microsalts, MS macrosalts, $1 / 2$ MS alone, MS alone were tested for aseptic seed germination. These experiments were conducted sequentially after the thorough study of remarks obtained in the previous experiment.

Two to three weeks old aseptic seedlings were used as explant source. Different seedling explants were excised form aseptically grown seedlings and planted on different media. These were subcultured for every 20 days. The results were recorded after the second passage and cultures that were contaminated were excluded. In the present investigation, all the experiments were repeated thrice and fifteen replicates per treatment were taken. The cultures were incubated at 2000 lux light under cool white, fluorescent tubes (Philips, India Make, 40 watt). The photo period regime was $16 \mathrm{~h}$ light $/ 8 \mathrm{~h}$ dark diurnal cycles maintained at a constant temperature of $25 \pm 2^{\circ} \mathrm{C}$. Morphogenetic potentiality was examined by culturing different seedling explants such as roots, hypocotyl, cotyledons, cotyledonary nodes, nodal explants, internodes, leaves, shoot tips etc. on MS medium supplemented with $2 \%$ sucrose and BAP 0.1 to $3 \mathrm{mg} / \mathrm{l}$. The morphogenic responses of the explants were recorded. Best explants for shoot regeneration were identified based on the number of shoots, shoot length and percentage of response. MS, $B_{5}$, WPM media supplemented with $2 \mathrm{mg} / \mathrm{l}$ BAP and $2 \%$ sucrose were used for screening the efficient medium on the organogenesis of various seedling explants. Criteria for medium selection include percentage of explants responded, average number of shoots, and shoot length per explant.

Morphogenic influence of different plant growth regulators and other organic supplements was further tested after the selection of best medium and best explant for shoot multiplication. Single shoot with 2 to 3 nodes were excised from multiple shoot cultures and transferred to elongation medium. MS $1 / 2$ strength, supplemented with auxins such as IAA, IBA, NAA (0.1 to $3 \mathrm{mg} / \mathrm{l})$ were used for rhizogenesis of regenerated shoots. After root induction, the plantlets were removed carefully from the test tubes and washed thoroughly under running tap water to remove the traces of agar adhering the plantlets. The plantlets were transferred to pots containing coarse sand and vermiculate (1:3) covered with polythene bags and incubated at $25 \pm 2^{\circ} \mathrm{C}$ for 10 to 15 days to ensure high humidity. MS quarter strength basal liquid medium was used during the period of acclimatization. Later small holes were made on the polythene bag to reduce the relative humidity. Gradually the pots were transferred to room temperature having diffuse light and finally plants were exposed to sunlight.

\section{RESULTS AND DISCUSSION}

\section{In vitro seed germination studies}

Among the three surface sterilants used, $0.1 \% \mathrm{HgCl}_{2}$ for 3 min was found to be an effective disinfectant and was also good at promoting germination. Of the different treatments, high percent frequency of germination was obtained by placing uniform, healthy seeds on $1 / 2$ strength MS medium. A germination frequency of $80 \%$ was recorded with in a period of $24 \mathrm{~h}$ after inoculation on medium. Within 14 days of culture, seedlings attained a height of $6.8 \mathrm{~cm}$ with 3 to 4 nodes. In the present study, it was observed that $1 / 2$ strength MS medium was effective for seed germination, as they do not require much ion supplementation for its further development.

\section{Multiple shoot induction}

\section{Explant evaluation}

Different seedling explants were tested for their ability to regenerate shoot buds by culturing on MS medium fortified with BAP and Kn separately with $2 \%$ sucrose and the results are tabulated. To regenerate shoot buds, maximum bud proliferation was observed on cotyledonary nodes (Figure 1). Axillary bud sprouting was observed from the 9th day of inoculation, shoot elongation started after 12 days of inoculation. Cotyledonary nodes cultured on MS medium fortified with BAP $1 \mathrm{mg} / \mathrm{l}$ showed highest number of multiple shoots (6.84 \pm 0.30 shoots/ explant) with average shoot length of $3.20 \pm 0.54$ (Table 1). The cotyledonary nodes proved to be better even on $\mathrm{Kn} 0.5 \mathrm{mg} / \mathrm{l}$ (3.42 \pm 0.30 shoots/ explant) than other explants for regeneration of shoots. Since the highest number of shoots was observed from cotyledonary nodes in all harmonal media, further shoot multiplication experiments were carried out with cotyledonary nodes. Regeneration potentiality of explants in the present study is in the following order: Cotyledonary node $>$ node $>$ Shoot tip.

\section{Media evaluation}

Media evaluation is a prerequisite step for efficient organogenesis in plant tissue culture. Bhojwani and Razdan (1983) suggested that in order to formulate 
Table 1. Effect of BAP and $\mathrm{Kn}$ on shoot initiation from seedling explants of $A$. amara.

\begin{tabular}{|c|c|c|c|c|c|c|c|c|c|}
\hline \multirow[b]{2}{*}{$\begin{array}{l}\text { Plant growth } \\
\text { regulator (mg/l) }\end{array}$} & \multicolumn{3}{|c|}{ Cotyledonary node } & \multicolumn{3}{|c|}{ Node } & \multicolumn{3}{|c|}{ Shoot Tip } \\
\hline & $\begin{array}{l}\% \text { of explants } \\
\text { responded }\end{array}$ & $\begin{array}{l}\text { No. of shoots } \\
\text { Mean } \pm \text { S.D }\end{array}$ & $\begin{array}{c}\text { Shoot } \\
\text { length }(\mathrm{cm}) \\
\text { Mean + S.D }\end{array}$ & $\begin{array}{l}\% \text { of explants } \\
\text { responded }\end{array}$ & $\begin{array}{l}\text { No. of shoots } \\
\text { Mean + S.D }\end{array}$ & $\begin{array}{c}\text { Shoot } \\
\text { length }(\mathrm{cm}) \\
\text { Mean + S.D }\end{array}$ & $\begin{array}{c}\% \text { of explants } \\
\text { responded }\end{array}$ & $\begin{array}{l}\text { No. of shoots } \\
\text { Mean + S.D }\end{array}$ & $\begin{array}{c}\text { Shoot } \\
\text { length }(\mathrm{cm}) \\
\text { Mean + S.D }\end{array}$ \\
\hline BAP 0.25 & 45 & $1.75 \pm 0.55$ & $1.50 \pm 0.35$ & 35 & $2.00 \pm 0.30$ & $1.20 \pm 0.40$ & 30 & $2.00 \pm 0.10$ & $1.50 \pm 1.42$ \\
\hline BAP 0.50 & 60 & $3.75 \pm 0.22$ & $2.60 \pm 0.25$ & 40 & $2.60 \pm 0.20$ & $1.25 \pm 0.35$ & 50 & $2.50 \pm 0.70$ & $2.00 \pm 0.20$ \\
\hline BAP 1.0 & 90 & $6.84 \pm 0.30$ & $3.20 \pm 0.54$ & 50 & $2.95 \pm 0.10$ & $1.60 \pm 0.20$ & 45 & $2.20 \pm 0.60$ & $1.80 \pm 0.38$ \\
\hline BAP 2.0 & 70 & $4.60 \pm 0.55$ & $3.00 \pm 0.31$ & 60 & $3.80 \pm 0.35$ & $1.80 \pm 0.45$ & 55 & $2.80 \pm 0.45$ & $2.10 \pm 0.25$ \\
\hline Kn 0.25 & 60 & $2.00 \pm 0.45$ & $4.80 \pm 0.35$ & 30 & $1.25 \pm 0.45$ & $1.10 \pm 0.30$ & 35 & $1.30 \pm 0.40$ & $2.35 \pm 0.05$ \\
\hline Kn 0.50 & 70 & $3.42 \pm 0.30$ & $2.00 \pm 0.60$ & 40 & $1.90 \pm 0.25$ & $1.20 \pm 0.50$ & 50 & $1.75 \pm 0.35$ & $2.90 \pm 0.40$ \\
\hline Kn 1.0 & 50 & $1.80 \pm 0.36$ & $1.75 \pm 0.30$ & 55 & $2.60 \pm 0.20$ & $1.40 \pm 0.30$ & 40 & $1.50 \pm 0.32$ & $2.50 \pm 0.45$ \\
\hline $\mathrm{Kn} 2.0$ & 45 & $1.65 \pm 0.25$ & $1.00 \pm 0.40$ & 45 & $2.20 \pm 0.50$ & $1.20 \pm 0.35$ & 30 & $1.10 \pm 0.30$ & $2.10 \pm 0.10$ \\
\hline
\end{tabular}

a suitable medium for a new system, it would be better to start with well known basal media such as MS, $B_{5}$ and WPM. In the present study, MS medium was found to be superior for the induction of more number of multiple shoots with high percent frequency. The percentage of response was highest in MS $(90 \%)$ followed by $\mathrm{B}_{5}(70 \%)$ and WPM (60\%).

\section{Effect of different carbon sources on morphogenesis}

Organogenesis may be influenced by the type of carbon source used in the media and this was tested by using $2 \%$ of different carbon source like glucose, fructose, sucrose and maltose. Though, the average number and average length of regenerated shoots was not much influenced by the type of carbon source, nature of response varied greatly. Among different carbon sources used, sucrose was unique in producing healthy and sturdy shoots with fast growth, showing $90 \%$ response. About $90 \%$ of cultures responded well at $2 \%$ sucrose concentration with a maximum of $3.60 \pm 0.35$ shoots / explant with an average length of $3.52 \pm 0.40 \mathrm{~cm}$

\section{Effect of different plant growth regulators on} shoot multiplication

The highest rate of micropropagation will often depend not only on the selection of the most suitable explant and medium, but also on the discovery of correct combination of growth regulators and modulation of hormone levels.

\section{Role of cytokinins on shoot multiplication}

Transversely, sectioned cotyledonary node explants were inoculated into each culture tube containing $15 \mathrm{ml}$ of the medium. Each culture contained a single explant and the mouth was covered with aluminum foil. In the present study, four cytokinins BAP $(0.1$ to $3 \mathrm{mg} / \mathrm{l}), \mathrm{Kn}$ (0.1 to 2 $\mathrm{mg} / \mathrm{l}) \mathrm{TDZ}(0.01$ to $1 \mathrm{mg} / \mathrm{l})$ and Zeatin (0.1 to 1 $\mathrm{mg} / \mathrm{l})$ were employed either singly or in various combinations for multiple shoot induction from cotyledonary nodes of $A$. amara (Table 2). Among the various concentrations of BAP tested for shoo proliferation at $1 \mathrm{mg} / \mathrm{l}$ cotyledonary nodes showed $80 \%$ of response with an average of $6.84 \pm 0.30$ shoots/explants and attained a length of $3.20 \pm$ $0.54 \mathrm{~cm}$ with 4 to 5 nodes with little basal callus
(Figure 2a). It was observed that increase in concentration of BAP increased basal callusing, with retardation of shoot growth.

Among different concentrations of $\mathrm{Kn}$ used for shoot multiplication, better response $(70 \%)$ was observed at $0.5 \mathrm{mg} / \mathrm{l}$ with a maximum of $3.42 \pm$ 0.30 shoots/explant and a length of $2.00 \pm 0.60$ $\mathrm{cm}$. Among various cytokinins tested, TDZ (0.01-1 $\mathrm{mg} / \mathrm{l})$ show a differential response. The concentration at which TDZ is most effective is 10 to 1000 times lower than other PGRs. Low concentrate of TDZ at $0.05 \mathrm{mg} / \mathrm{l}$ show fasciated shoots, which differ markedly from normal shoots, appearing as though several shoots are fused together to form a flattened stem. Shoot regeneration efficiency of cotyledonary node was $65 \%$ at $0.25 \mathrm{mg} / \mathrm{l}$ Zeatin. On the whole $\mathrm{Kn}, \mathrm{TDZ}$ and Zeatin were inferior to BAP in terms of percentage of response, number of shoots/explant and shoot length.

\section{Effect of cytokinin combination on shoot multiplication}

Different combinations of cytokinins were used to 
Table 2. Effect of various cytokinins on multiple shoot induction from cotyledonary nodes of $A$. amara on MS medium.

\begin{tabular}{lcccc}
\hline $\begin{array}{l}\text { Growth regulators } \\
\text { (mg/l) }\end{array}$ & \% of response & $\begin{array}{c}\text { No. of shoots / explants } \\
\text { (Mean } \pm \text { S.D) }\end{array}$ & $\begin{array}{c}\text { Shoot length (cm) } \\
\text { (Mean } \pm \text { S.D) }\end{array}$ & $\begin{array}{c}\text { Basal } \\
\text { Callus }\end{array}$ \\
\hline BAP & & & & \\
0.1 & 30 & $1.60 \pm 0.40$ & $1.00 \pm 0.30$ & + \\
0.25 & 45 & $1.75 \pm 0.55$ & $1.50 \pm 0.35$ & + \\
0.50 & 60 & $3.75 \pm 0.22$ & $2.60 \pm 0.25$ & + \\
1.0 & 90 & $6.84 \pm 0.30$ & $3.20 \pm 0.54$ & ++ \\
2.0 & 70 & $4.60 \pm 0.55$ & $3.00+0.31$ & ++ \\
3.0 & 50 & $2.80 \pm 0.50$ & $2.00 \pm 0.10$ & ++ \\
Kn & & & & + \\
0.1 & & & $2.60 \pm 0.25$ & + \\
0.25 & 40 & $1.45 \pm 0.20$ & $4.80 \pm 0.35$ & + \\
0.5 & 60 & $2.00 \pm 0.45$ & $2.00 \pm 0.60$ & + \\
1.0 & 70 & $3.42 \pm 0.30$ & $1.75 \pm 0.30$ & + \\
2.0 & 50 & $1.80 \pm 0.36$ & $1.00 \pm 0.40$ & + \\
TDZ & $1.65 \pm 0.25$ & & + \\
0.05 & 45 & & & + \\
0.1 & & & & + \\
0.25 & & $1.30 \pm 0.72$ & & + \\
0.5 & 50 & $1.00 \pm 0.65$ & $\mathrm{CP}$ & + \\
1.0 & $\mathrm{CP}$ & $\mathrm{CP}$ & + \\
Zeatin & $\mathrm{CP}$ & $\mathrm{CP}$ & + \\
0.1 & 40 & $\mathrm{CP}$ & $1.50 \pm 0.20$ & + \\
0.25 & 35 & & $1.75 \pm 0.40$ & + \\
0.5 & 30 & $2.10 \pm 0.45$ & $\mathrm{NR}$ & + \\
\hline .0 & 30 & $2.80 \pm 0.24$ & & + \\
\hline
\end{tabular}

+, less; ++, Moderate; +++, Profuse; CP, Callus production; NR, No response.
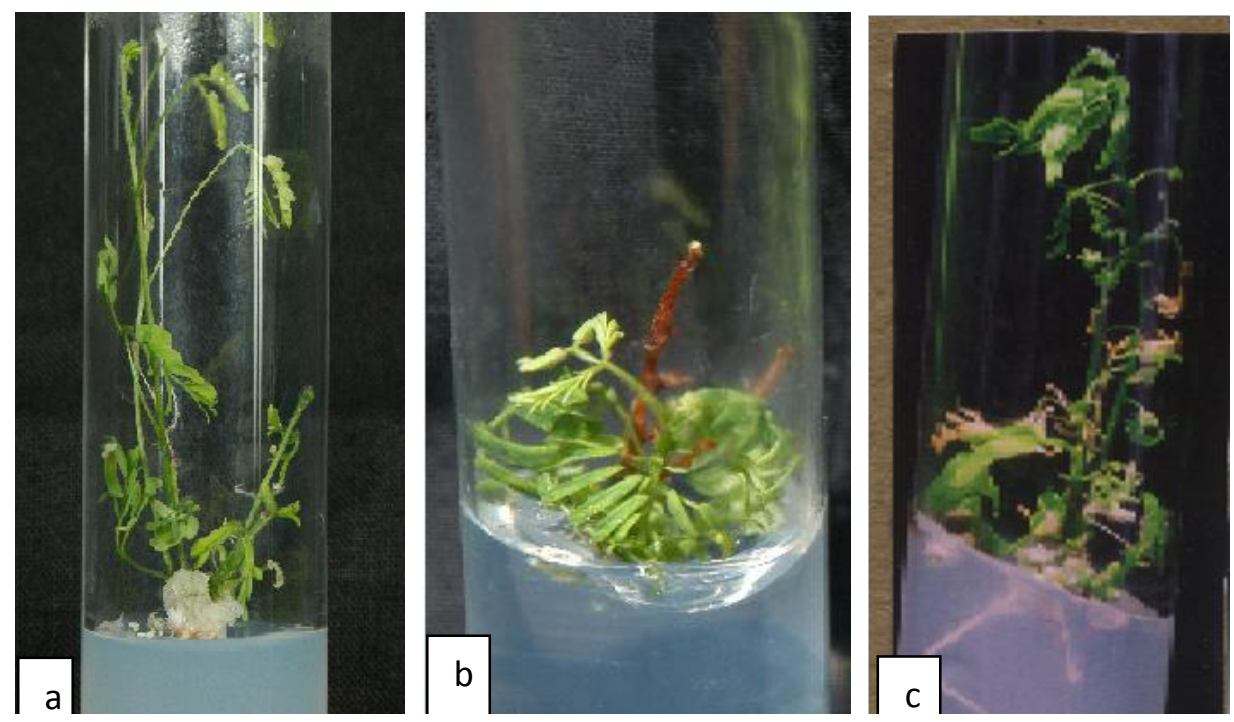

Figure 2. Multiple shoot induction of cotyledonary node on MS medium with a, BAP $1 \mathrm{mg} / \mathrm{l}$; b, BAP $1 \mathrm{mg} / \mathrm{l}+\mathrm{Kn} 2 \mathrm{mg} / \mathrm{l} ; \mathbf{c}$, BAP $1 \mathrm{mg} / \mathrm{l}+\mathrm{NAA} 1 \mathrm{mg} / \mathrm{l}$. 
Table 3. Effect of various cytokinin combination on multiple shoot induction from cotyledonary nodes of $A$. amara on MS medium.

\begin{tabular}{|c|c|c|c|c|c|c|}
\hline \multicolumn{3}{|c|}{ Plant growth regulators (mg/l) } & \multirow{2}{*}{$\begin{array}{c}\% \text { of } \\
\text { response }\end{array}$} & \multirow{2}{*}{$\begin{array}{l}\text { No. of shoots / explants } \\
\text { (Mean } \pm \text { S.D) }\end{array}$} & \multirow{2}{*}{$\begin{array}{l}\text { Shoot length(cm) } \\
\text { (Mean } \pm \text { S.D) }\end{array}$} & \multirow{2}{*}{$\begin{array}{l}\text { Basal } \\
\text { Callus }\end{array}$} \\
\hline BAP & $\mathbf{K N}$ & Zeatin & & & & \\
\hline 1.0 & 0.5 & - & 50 & $3.25 \pm 0.60$ & $1.50 \pm 0.30$ & + \\
\hline 1.0 & 1.0 & - & 60 & $5.35 \pm 0.50$ & $1.80 \pm 0.25$ & + \\
\hline 1.0 & 2.0 & - & 80 & $8.30 \pm 0.20$ & $2.00 \pm 0.40$ & + \\
\hline 2.0 & 0.5 & - & 45 & $3.35 \pm 0.30$ & $2.15 \pm 0.25$ & ++ \\
\hline 2.0 & 1.0 & - & 70 & $6.20 \pm 0.50$ & $3.45 \pm 0.35$ & + \\
\hline 2.0 & 2.0 & - & 55 & $4.45 \pm 0.90$ & $2.20 \pm 0.20$ & ++ \\
\hline- & 0.5 & 0.1 & 50 & $2.80 \pm 0.45$ & $1.50 \pm 0.20$ & - \\
\hline- & 1.0 & 0.25 & 65 & $4.20 \pm 0.70$ & $1.95 \pm 0.35$ & - \\
\hline- & 2.0 & 0.5 & 40 & $2.50 \pm 0.25$ & $1.35 \pm 0.45$ & - \\
\hline 1.0 & - & 0.1 & 40 & $3.50 \pm 0.20$ & $1.00 \pm 0.30$ & + \\
\hline 1.0 & - & 0.25 & 45 & $4.10 \pm 0.35$ & $1.00 \pm 0.45$ & + \\
\hline 1.0 & - & 0.5 & 60 & $6.80 \pm 0.20$ & $1.85 \pm 0.20$ & + \\
\hline 1.0 & - & 1.0 & 50 & $4.35 \pm 0.50$ & $1.28 \pm 0.40$ & + \\
\hline 2.0 & - & 0.10 & 40 & $2.20 \pm 0.45$ & $1.00 \pm 0.25$ & ++ \\
\hline 2.0 & - & 0.3 & 55 & $2.80 \pm 0.50$ & $1.25 \pm 0.50$ & + \\
\hline 2.0 & - & 0.5 & 40 & $2.50 \pm 0.30$ & $0.90 \pm 0.35$ & ++ \\
\hline
\end{tabular}

find out a suitable nutrient medium that would promote high rate of shoot multiplication without the intervention of callus. The explants were cultured on MS medium fortified with different combinations of BAP $+\mathrm{Kn}$, BAP + Zeatin, $\mathrm{Kn}+$ Zeatin, and $2 \%$ sucrose. Fifteen and thirty days after placement of the explants of cultures exhibiting shoot proliferation and number of shoots/explant were determined. Multiple shoot induction from cotyledonary nodes occurred maximum on MS medium fortified with BAP $1 \mathrm{mg} / \mathrm{l}+\mathrm{Kn} 2 \mathrm{mg} / \mathrm{l}$ (Figure 2b). The percentage of response was 80 and about $8.30 \pm 0.20$ shoots/explant were formed and the shoot length was $2.00 \pm 0.40 \mathrm{~cm}$. Increase in concentration of BAP to $2 \mathrm{mg} / \mathrm{l}$ in combination with $\mathrm{Kn} 1 \mathrm{mg} / \mathrm{l}$ enhanced shoot length to $3.45 \pm 0.35 \mathrm{~cm}$ and reduced shoot number with little basal callusing (Table 3). Among the different combinations of cytokinins observed, the synergistic effect of BAP and $\mathrm{Kn}$ was effective than either use of single harmone. This study was further weighed by previous survey of literature (Benneth and Davies, 1986; Rahman et al., 1993; Bhat et al., 1995; Anuradha and Pullaiah, 2001).

\section{Effect of auxin and cytokinin on multiple shoot induction}

Many aspects of cell growth, cell differentiation and organogenesis in tissue and organ cultures have been found to be controlled by an interaction between cytokinins and auxins. In the present study, various combinations of cytokinins and auxins were used at different concentrations for rapid shoot proliferation (Table 4). However among the different combinations used, BAP $1 \mathrm{mg} / \mathrm{l}+\mathrm{NAA} 1 \mathrm{mg} / \mathrm{l}$ was crucial for multiple shoot induction, as it produced $6.28 \pm 0.25$ shoots with a length of $2.50 \pm 0.35 \mathrm{~cm}$ (Figure 2c). Media containing
BAP $1 \mathrm{mg} / \mathrm{l}+$ IAA $0.5 \mathrm{mg} / \mathrm{l}$ responded well with a maximum of $3.44 \pm 0.65 \mathrm{~cm}$. About $60 \%$ shoot induction was observed on medium supplemented with BAP $1 \mathrm{mg} / \mathrm{l}$ + 2.4 D $0.5 \mathrm{mg} / \mathrm{l}$. Among different combinations of auxins tested with kinetin, $\mathrm{Kn} 0.5 \mathrm{mg} / \mathrm{l}+\mathrm{NAA} 1 \mathrm{mg} / \mathrm{l}$ was effective producing $4.00 \pm 0.70$ shoots/explant with a maximum length of $2.35 \pm 0.20 \mathrm{~cm}$ (Table 5). Media containing Zeatin $0.25 \mathrm{mg} / \mathrm{l}+\mathrm{NAA} 2 \mathrm{mg} / \mathrm{l}$ induced $5.10 \pm 0.15$ shoots/explant with $2.15 \pm 0.15 \mathrm{~cm}$ of shoot length. On the whole, cytokinin in combination with NAA was found to be more effective in rapid shoot proliferation and also root induction. Further increase or decrease in the concentration of either BAP or NAA did not enhance the shoot number. But the addition of NAA with optimal concentration of BAP significantly reduced the frequency of shoot formation compared to BAP alone. This result was supported by Kumar et al. (1998) in Albizia procera, Sinha et al. (2000) in Albizia chinensis and Ramamurthy and Savithramma (2003) in Albizia amara.

\section{Shoot elongation}

Single shoot was excised from multiple shoot culture and transferred to MS medium supplemented with low concentration of $\mathrm{Kn}$. Maximum shoot length of $4.80 \pm$ $0.35 \mathrm{~cm}$ was attained with 3 to 4 nodes on MS medium fortified with $\mathrm{Kn} 0.25 \mathrm{mg} / \mathrm{l}$. Elongated shoots after one sub-culture were subjected to different concentrations of auxins to induce rhizogenesis.

\section{Rhizogenesis}

Elongated shoots with 3 to 4 nodes were transferred to different rooting media to induce rhizogenesis. Root 
Table 4. Effect of BAP with various concentrations of auxin on multiple shoot induction from cotyledonary node of $A$. amara on MS medium.

\begin{tabular}{|c|c|c|c|c|c|c|c|}
\hline \multicolumn{4}{|c|}{ Plant growth regulators $(\mathrm{mg} / \mathrm{l})$} & \multirow{2}{*}{$\begin{array}{l}\% \text { of } \\
\text { response }\end{array}$} & \multirow{2}{*}{$\begin{array}{c}\text { No. of shoots / explants } \\
(\text { Mean } \pm \text { S.D) }\end{array}$} & \multirow{2}{*}{$\begin{array}{l}\text { Shoot length }(\mathrm{cm}) \\
\text { (Mean } \pm \text { S.D) }\end{array}$} & \multirow{2}{*}{ Basal Callus } \\
\hline BAP & IAA & NAA & $2,4 \mathrm{D}$ & & & & \\
\hline 1 & - & 0.10 & - & 50 & $4.20 \pm 0.20$ & $1.25 \pm 0.35$ & + \\
\hline 1 & - & 0.25 & - & 55 & $4.80 \pm 0.75$ & $2.00 \pm 0.15$ & + \\
\hline 1 & - & 0.50 & - & 60 & $5.75 \pm 0.38$ & $2.20 \pm 0.45$ & + \\
\hline 1 & - & 1.00 & - & 80 & $6.28 \pm 0.25$ & $2.50 \pm 0.35$ & + \\
\hline 1 & - & 2.00 & - & 50 & $4.15 \pm 0.68$ & $1.50 \pm 0.58$ & ++ \\
\hline 1 & 0.10 & - & - & 30 & $1.80 \pm 0.60$ & $1.00 \pm 0.25$ & + \\
\hline 1 & 0.25 & - & - & 40 & $2.50 \pm 0.45$ & $1.40 \pm 0.30$ & + \\
\hline 1 & 0.50 & - & - & 45 & $3.40 \pm 0.65$ & $1.85 \pm 0.75$ & + \\
\hline 1 & 1.00 & - & - & 35 & $2.20 \pm 0.28$ & $1.25 \pm 0.35$ & + \\
\hline 1 & - & - & 0.10 & 30 & $2.55 \pm 0.25$ & $1.06 \pm 0.20$ & + \\
\hline 1 & - & - & 0.25 & 40 & $3.00 \pm 0.75$ & $1.25 \pm 0.37$ & + \\
\hline 1 & - & - & 0.50 & 60 & $4.10 \pm 0.15$ & $1.50 \pm 0.30$ & + \\
\hline 1 & - & - & 1.00 & 50 & $3.75 \pm 0.22$ & $1.28 \pm 0.38$ & ++ \\
\hline
\end{tabular}

Table 5. Effect of $\mathrm{Kn}$ and Zeatin with various concentrations of auxin on multiple shoot induction from cotyledonary nodes of $A$. amara on MS medium.

\begin{tabular}{|c|c|c|c|c|c|c|c|c|}
\hline \multicolumn{5}{|c|}{ Plant growth regulators $(\mathrm{mg} / \mathrm{l})$} & \multirow{2}{*}{$\begin{array}{c}\% \text { of } \\
\text { response }\end{array}$} & \multirow{2}{*}{$\begin{array}{c}\text { No. of shoots / explants } \\
(\text { Mean } \pm S . D)\end{array}$} & \multirow{2}{*}{$\begin{array}{l}\text { Shoot length }(\mathrm{cm}) \\
(\text { Mean } \pm \text { S.D) }\end{array}$} & \multirow{2}{*}{ Basal Callus } \\
\hline Kn & ZEA & IAA & IBA & NAA & & & & \\
\hline 0.5 & & 0.25 & & & 30 & $2.15 \pm 0.68$ & $1.90 \pm 0.35$ & + \\
\hline 0.5 & & 0.50 & & & 20 & $1.55 \pm 0.70$ & $1.25 \pm 0.37$ & + \\
\hline 0.5 & & & 1.0 & & 70 & $4.00 \pm 0.70$ & $2.35 \pm 0.20$ & + \\
\hline 0.5 & & & 2.0 & & 50 & $3.75 \pm 0.22$ & $2.00 \pm 0.45$ & + \\
\hline 0.5 & & & & 0.5 & 40 & $2.15 \pm 0.15$ & $2.45 \pm 0.25$ & ++ \\
\hline 0.5 & & & & 1.0 & 55 & $2.50 \pm 0.25$ & $2.80 \pm 0.30$ & ++ \\
\hline & 0.25 & 0.25 & & & 35 & $1.85 \pm 0.10$ & $1.28 \pm 0.38$ & + \\
\hline & 0.25 & 0.50 & & & 20 & $1.25 \pm 0.65$ & $1.00 \pm 0.10$ & + \\
\hline & 0.25 & & 1.0 & & 50 & $3.95 \pm .50$ & $1.85 \pm 0.10$ & + \\
\hline & 0.25 & & 2.0 & & 60 & $5.10 \pm 0.15$ & $2.15 \pm 0.15$ & + \\
\hline & 0.25 & & & 0.5 & 40 & $2.45 \pm 0.10$ & $1.95 \pm 0.50$ & ++ \\
\hline
\end{tabular}

induction experiments from in vitro raised shoots of Albizia amara were performed at different concentrations of $M S$ and $B_{5}$ salts individually supplemented with NAA 1 $\mathrm{mg} / \mathrm{l}$. High frequency of rooting with $80 \%$ was observed on half strength MS medium on an average of $3.50 \pm$ $0.45 \mathrm{roots} /$ culture and a length of $5.25 \pm 0.12 \mathrm{~cm}$ (Figure 3) (Table 6). Other concentrations of MS salts that is, full strength and quarter strength was less effective. However, all the three concentrations of $B_{5}$ salts $(1 / 4,1 / 2$ and full strength) promoted low percent of rhizogenesis. Rooting assay was performed by transferring healthy and sturdy shoots (4 to $5 \mathrm{~cm}$ long) on $1 / 2$ strength MS medium fortified with different auxins (IAA, IBA and NAA) applied singly at various concentrations (Table 7 ). Of this half strength MS medium containing NAA $1 \mathrm{mg} / \mathrm{l}$ induced rooting in $80 \%$ of the shoots within 15 days. Each shoot developed 3 to 4 roots after 20 days. Even lateral root induction was also observed. Rooting efficiency decreased at a concentration above and below $1 \mathrm{mg} / \mathrm{l}$ NAA; about $3.50 \pm 0.45$ roots/shoot with a average length of $5.25 \pm 0.12 \mathrm{~cm}$ was observed.

\section{Acclimatization of rooted plantlets}

Acclimatization and hardening are the most important aspects for micropropagated tree species. In vitro hardening can be achieved by decreasing the water potential of the medium and reducing humidity in culture vessel. In vitro regenerated complete plantlets of $A$. amara were taken out of the rooting media and agar traces were removed by washing with distilled water for 10 to 15 min. Fungal growth rate was checked by 


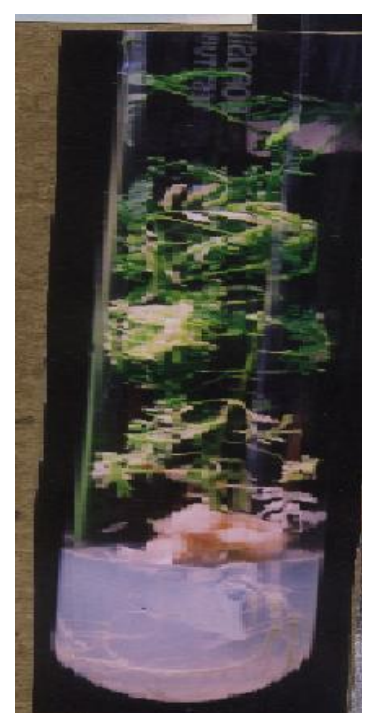

Figure 3. Root induction on $1 / 2$ strength MS medium with NAA $1 \mathrm{mg} / \mathrm{l}$.

Table 6. Rooting efficiency of in vitro raised shoots of $A$. amara cultured on different media with NAA (1 mg/l).

\begin{tabular}{lcccc}
\hline Types of medium & \% of response & No. of roots / shoots Mean \pm S.D. & Length of roots $(\mathbf{c m})$ Mean \pm S.D. & Days of rooting \\
\hline MS full strength & 55 & $2.50 \pm 0.15$ & $3.50 \pm 0.33$ & 20 \\
MS 1/2 strength & 80 & $3.50 \pm 0.45$ & $5.25 \pm 0.12$ & 12 \\
MS 1/4 strength & 45 & $2.35 \pm 0.25$ & $3.15 \pm 0.15$ & 25 \\
B5 full strength & 30 & $1.00 \pm 0.25$ & $0.90 \pm 0.28$ & 35 \\
B5 1/2 strength & 50 & $1.35 \pm 0.32$ & $1.00 \pm 0.15$ & 30 \\
B5 1/4 strength & 20 & $1.00 \pm 0.00$ & $0.85 \pm 0.18$ & 40 \\
\hline
\end{tabular}

Table 7. -Effect of various auxins on root induction from shoots of $A$. amara on half strength MS medium.

\begin{tabular}{|c|c|c|c|c|c|}
\hline Auxins & $\begin{array}{c}\text { Concentrations } \\
(\mathrm{mg} / \mathrm{l})\end{array}$ & $\begin{array}{c}\% \text { of } \\
\text { response }\end{array}$ & $\begin{array}{l}\text { Mean No. of } \\
\text { roots / culture } \\
\text { (Mean } \pm \text { S.D.) }\end{array}$ & $\begin{array}{l}\text { Length of } \\
\text { roots }(\mathrm{cm}) \\
(\text { Mean + S.D.) }\end{array}$ & Nature of response \\
\hline \multirow[t]{5}{*}{ IAA } & 0.10 & 30 & $1.55 \pm 0.15$ & $1.45 \pm 0.35$ & Thin and short roots \\
\hline & 0.25 & 50 & $2.35 \pm 0.28$ & $2.00 \pm 0.28$ & Thin and medium roots with nodules \\
\hline & 0.50 & 20 & $1.20 \pm 0.30$ & $1.25 \pm 0.20$ & No response \\
\hline & 1.00 & 0 & NR & NR & No response \\
\hline & 2.00 & 0 & NR & NR & No response \\
\hline \multirow[t]{5}{*}{ IBA } & 0.10 & 0 & NR & NR & No response \\
\hline & 0.25 & 20 & $1.10 \pm 0.25$ & $1.00 \pm 0.25$ & Thin and very short roots \\
\hline & 0.50 & 30 & $2.20 \pm 0.12$ & $1.05 \pm 0.50$ & Thick and short roots \\
\hline & 1.00 & 25 & $1.35 \pm 0.25$ & $1.00 \pm 0.60$ & Thick and very short roots \\
\hline & 2.00 & 0 & NR & NR & No response \\
\hline \multirow[t]{5}{*}{ NAA } & 0.10 & 30 & $1.80 \pm 0.40$ & $2.85 \pm 0.15$ & Thick and long roots \\
\hline & 0.25 & 40 & $2.00 \pm 0.35$ & $3.30 \pm 0.27$ & Thick and long roots \\
\hline & 0.50 & 65 & $2.90 \pm 0.37$ & $4.50 \pm 0.33$ & Thick and long roots \\
\hline & 1.00 & 80 & $3.50 \pm 0.45$ & $5.25 \pm 0.12$ & Thick and long tap root system with lateral roots \\
\hline & 2.00 & 60 & $2.35 \pm 0.35$ & $4.30 \pm 0.05$ & Thick and long roots \\
\hline
\end{tabular}




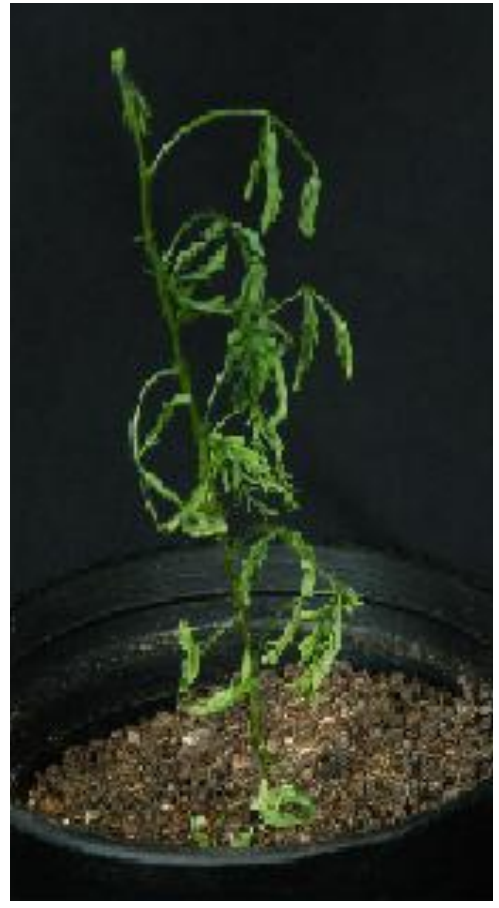

Figure 4. Acclimatized plant after two weeks.

spraying $0.5 \%(\mathrm{w} / \mathrm{v})$ Benolate fungicide. Then plantlets were transferred to pots of size $7.6 \mathrm{~cm}^{2}$ containing sterile peat moss and vermiculate (1:1) and incubated for two weeks at $25 \pm 2^{\circ} \mathrm{C}$ (2000 lux) for $16 \mathrm{~h}$ photoperiod. The pots were enclosed in plastic covers and small holes were punched to decrease the relative humidity. During the period, liquid quarter strength MS basal nutrient medium was provided. Gradually, pots were transferred to room temperature having diffuse light. Later, pots were shifted to green house and size of the holes was increased. Covers were removed after 6 weeks and plants were acclimatized in normal soil (Figure 4). About eight to nine true-to-type plantlets of $A$. amara were raised in vitro from single cotyledonary node explant. But successful transfer of in vitro raised plantlets to soil through hardening is poor $(50 \%)$ due to premature defoliation of leaflets.

\section{Conclusion}

We have established a protocol for direct in vitro regeneration system for conservation and micropropagation of $A$. amara from cotyledonary nodal explants. MS medium fortified with BAP $1 \mathrm{mg} / \mathrm{l}+\mathrm{Kn} 2$ $\mathrm{mg} / \mathrm{l}$, was effective in inducing multiple shoots from cotyledonary node explants. In vitro rooting experiments were successful on half strength MS medium fortified with NAA $1 \mathrm{mg} / \mathrm{l}$.

\section{REFERENCES}

Anuradha T, Pullaiah T (2001). In vitro germination studies on endangered tree taxon Albizia thompsonii Brandis. Proc. A.P. Akad. Sci. 5:137-140.

Ayoub SMH, Yankov LK (1986). The molluscicidal factor of tannin bearing plants. Int. J. Crude Drug Res. 21:16-18.

Benneth LK, Davies FT (1986). In vitro propagation of Quercus shumardii. Hortic. Sci. 212:1045-1047.

Bhat SR, Chandel KPS, Mallik SK (1995). Plant regeneration from various explants of cultivated Piper species. Plant Cell Rep. 14:398402.

Bhojwani SS, Razdan MK (1983). Plant tissue culture: Theory and Practice. Elsevier Science, Amsterdam.

Kashyapa K, Ramesh C (1992). The useful plants of India. Publications and Information, Directorate, CSIR, New Delhi.

Kumar S, Sarkar AK, Kunhikannan C (1998). Regeneration of plants from leaflet explants of tissue culture raised safed siris (Albizia procera). Plant Cell Tiss. Org. Cult. 54:137-143.

Mar W, Tan GT, Cordell GA, Pezzuto JW, Jurcic K, Offer mann F, Redi K, Steinke B, Wagnes H (1991). Biological activity of novel macrocyclic alkaloids (budmunchiamines) from Albizia amara detected on the basis of interaction with DNA. J. Nat. Prod. 54:15311542.

Rahman SM, Hussain M, Biswas BK, Joarder OI, Islam R (1993). Micropropagation of Caesalpinia pulcherrima through nodal bud culture of mature tree. Plant Cell Tiss. Org. Cult. 32:363-365.

Ramamurthy N, Savithramma N (2003). Shoot bud regeneration from leaf explants of Albizia amara Boiv. Indian J. Plant Physiol. 8:372376.

Sinha RK, Majumdar K, Sinha S (2000). In vitro differentiation and plant regeneration of Albizia chinensis (Osb.) Merr. In vitro Cell. Biol. Plant 36:370-373. 